\title{
Frykten for et samfunn uten Downs syndrom
}

\author{
Berge Solberg
}

Det er muligens ikke lenger et spørsmål om, men når mennesker med Downs syndrom ikke lenger finnes blant oss. Moderne medisinsk teknologi brukt $i$ masseundersøkelser av gravide, tilsier at det nesten ikke behøver å bli født mennesker med Downs syndrom ifremtiden. I den politiske debatten iflere av de nordiske landene er dette kontroversielt. Det handler om et samfunn der det er plass til alle, hevdes det. På samme tid tas moderne genteknologi i bruk for bl.a. å forhindre at mennesker disponert for Huntingtons sykdom eller arvelig brystkreft blir født. Om noen generasjoner kan slike sykdommer vare utryddet. Dette påkaller imidlertid ikke henvisninger til «sortering» og «seleksjon». I denne artikkelen undersøkes de viktigste forutsetningene for hvorfor fosterdiagnostikk på noen indikasjoner vekker etisk debatt, mens det ikke skjer $i$ andre tilfeller. Det argumenteres for at den medisinske forståelsen av alvorlighetsgrad ved en sykdom/funksjonshemming ikke gir oss nøkkelen til å forstå den etiske bekymringen rundt seleksjon. Identitets- og anerkjennelsesproblematikk, hevdes det, er kjernen $i$ kontroversene rundt fosterdiagnostikk $i$ Norden. Derfor står det noe vesentlig på spill i fosterdiagnostikkdebatten. Men bare for noen grupper.

Nøkkelord: fosterdiagnostikk, identitet, anerkjennelse, Downs syndrom

\section{Bakgrunn}

Et samfunn uten Downs syndrom ville tidlig på 1900-tallet fremstått som et ubetinget gode i Norden. Datidens eugeniske politikk var innrettet mot kampen mot «aandssvakhet» og frykten for stadig større utbredelse i senere generasjoner etter hvert som velferdsstatene ble bygd ut (Broberg \& RollHansen 1996). I dag er situasjonen annerledes. Fosterdiagnostikk er innført 
som et tilbud til gravide. Diskusjonen i de nordiske landene går på hvorvidt alle gravide eller bare noen skal få tilbud om ulike typer tester og undersøkelser. Fosterdiagnostikkens målsetting hevdes ikke å være forebygging av funksjonshemmede mennesker, men heller å ivareta den individuelle kvinnen eller paret gjennom å berolige engstelige gravide, hjelpe familier med arvelig sykdom til å få friske barn, eller rett og slett sikre alle gravide valgfrihet, slik det danske screeningprogrammet for Downs syndrom begrunner tilbudet (Sundhedsstyrelsen 2003). Samtidig vil screeningsprogrammene oppdage de aller fleste tilfeller av Downs syndrom i mors liv. Dersom etter hvert alle danske gravide velger nakkefoldscanning, og de velger abort ved påvist Downs syndrom, er det beregnet at det kun vil bli født seks mennesker med Downs syndrom hvert år i Danmark (Westengård 2006). Med eventuelt ytterligere forbedret teknologi i nær fremtid er det altså en reell mulighet for at det nesten ikke vil eksistere mennesker med Downs syndrom i Norden i fremtiden.

At selvbestemmelse og autonomi alene er basis for fosterdiagnostikken, kan betviles, og bl.a. Christian Munthe (1996) har forsøkt å påvise hvordan fosterdiagnostikken er en kompleks blanding av både hensynet til parets autonomi, ønsket om forebygging av funksjonshemming i samfunnet og ønsket om økonomiske besparelser ved å redusere antallet funksjonshemmede mennesker som kommer til verden. Hensikten med denne artikkelen er imidlertid ikke å forfølge denne kritikken. Her er poenget snarere å ta utgangspunkt i en «ideell» verden: Gitt at vi aksepterer at fosterdiagnostikk i Norden i dag handler om autonomi for paret, hvorfor skulle da screening for Downs syndrom være et problem?

\section{Medisinsk kontra etisk alvorlighetsskala}

Også i en autonomimodell må samfunn og helsevesen til en viss grad ta stilling til hvilke sykdommer og funksjonshemminger som kan anses som alvorlige nok til å bli testet for. Rettede testtilbud som nakkefoldscanning for Downs syndrom eller preimplantasjonsdiagnostikk (PGD) for bestemte arvelige sykdommer har ført til harde debatter i flere nordiske land om hvorvidt helsevesenet med dette uttrykker oppfatninger om liv som ikke er verdt å leve. Det fryktes at man glir vekk fra testing og bortvalg av alvorlig sykdom og funksjonshemming over mot mindre alvorlige tilstander. Den moralske holdbarheten av et testilbud synes å være proporsjonal med alvorlighetsgraden av tilstanden det testes for. Jo mer alvorlig tilstand vi står overfor, desto mer moralsk forsvarlig er det å gjøre fosterdiagnostikk. I denne artikkelen argumenteres det for at en slik fremstilling bare delvis fanger det som står på spill i de etiske debattene omkring fosterdiagnostikken. 
Den medisinske alvorlighetsskalaen deler diagnosegruppene inn i ulike alvorlighetsgrader. De mest alvorlige tilstandene er tilstander som er uforenlige med liv. Acrani, eller foster uten hjerne, er en slik tilstand. Dødelige eller nesten dødelige tilstander vekker ingen etisk debatt når det gjelder fosterdiagnostikk og abort. Det er riktignok et diskusjonstema om det er bedre for mor å gjøre en provosert abort på et foster som uansett kommer til å dø, eller om det oppleves bedre å la naturen gå sin gang (Skjei 1992; Getz 2003). Men dette er ikke primært et samfunnsetisk spørsmål.

De store samfunnsetiske kontroversene kommer når man beveger seg vekk fra dødelige tilstander til alvorlige tilstander som er fullt forenlig med liv. Et sted på denne linjen finner man Downs syndrom. Downs syndrom er et tungtveiende abortmotiv for mange. For andre er det uetisk at diagnosen er gyldig abortindikasjon. Downs syndrom er dermed en kontroversiell diagnose, tilsynelatende fordi det ikke er enighet om den nøyaktige plasseringen mellom svært alvorlig og mindre alvorlig tilstand.

Logikken videre burde i tråd med dette være at bortvalg av fremtidige mennesker med mindre alvorlige avvik enn Downs syndrom er etisk mer problematisk. Mindre funksjonsnedsettelser eller sykdom som bryter ut først sent i livet, burde være dårligere grunner for abort eller embryoutvelgelse enn kromosomavvik. I Norge formulerte Regjeringen seg omtrent slik da man i 2007 la frem nye regler for regulering av preimplantasjonsdiagnostikk (PGD). Her ble det understreket at PGD bare skulle være aktuelt for svært alvorlig sykdom, og en komité skulle vurdere innslaget av smerter, belastninger og redusert livslengde (Helse- og omsorgsdepartementet 2007). Tilsvarende restriktive tone gjennomsyrer den svenske loven om genetisk integritet, og begrensningen av PGD til å gjelde for «[...] allvarlig monogen eller kromsomal ärftlig sjukdom, som innebär hög risk att få barn med en genetisk sjukdom eller skada» (Socialdepartementet 2004). En utglidning av denne praksisen ville kunne lede til bortvalg av fremtidige mennesker på et «lettvint grunnlag», og derfor ønsket man i lovverket å understreke «alvoret» som må være knyttet til sykdommene og funksjonshemmingene som velges bort. En norsk politiker formulerte i 2005 denne redselen slik, konfrontert med preimplantasjondiagnostikkens muligheter: «Jeg ser for meg et vanvittig sorteringssamfunn der barn ikke får lov å vokse opp på grunn av feil øyenfarge.» (Magerøy 2005).

Men det viser seg at logikken ikke følges. Det er ikke den medisinske alvorlighetsskalaen som kan forklare etisk-politisk kontrovers omkring «seleksjon» og «sortering» i de nordiske landene. Det er for eksempel hevet over enhver tvil at en tilstand som Klinefelter syndrom er en mindre alvorlig tilstand enn Downs syndrom. Klinefelter gir opphav til infertilitet, økt risiko for lærevansker og i noen tilfeller psykiske problemer. Men det er samtidig mennesker som vil leve normale liv, og som sågar tilbys assistert befruktning for å bøte på sin infertilitet og bli foreldre. Til tross for at avvi- 
ket kan betegnes som mindre alvorlig, gjøres det fosterdiagnostikk og abort ved Klinefelter. I Danmark viser en studie at 70 prosent av fostrene som oppdages med Klinefelter, aborteres (Bojesen et al. 2003). Likevel vekker ikke slike bortvalg den samme offentlige «verdidebatten» som bortvalget av Downs syndrom. Forskjellen i forekomst og antall aborter kan selvsagt spille en rolle, men vi vet godt fra bioetikken - for eksempel i saker om PGD og redningssøsken - at enkeltsaker kan vekke stor etisk kontrovers. Så hvorfor er det så mye fokus på Downs syndrom?

\section{Beskjeden fra fosterdiagnostikk og selektiv abort}

For å forstå denne paradoksale situasjonen - at diagnostikk og abort ved mindre avvik som Klinefelter syndrom ikke vekker intens etisk-politisk debatt, mens diagnostikk og abort ved alvorligere avvik som Downs syndrom gjør det - kan det være fornuftig å studere den typiske argumentasjonen i kritikken av fosterdiagnostikken.

Siden alle de nordiske landene har lover som gir kvinner nokså lett tilgang til selektiv abort, så er ikke abort nøkkelen til å forstå de etiske debattene om fosterdiagnostikk. Riktignok kan man for eksempel i Sverige gjøre abort frem til utgangen av uke 18 uten å måtte oppgi en eneste grunn for ens valg. I Norge, Danmark, Island og Finland må man i alle landene ved en senabort i for eksempel 16. uke henvise til lovfestede årsaker for å kunne få innvilget abort (Danmark og Norge har selvbestemt abort til utgangen av 12. uke). Men disse forskjellene påvirker ikke den etiske debatten om fosterdiagnostikken. I Norge argumenterer enkelte for at abortlovens paragraf $2 \mathrm{c}$ som tillater abort ved alvorlig sykdom og skade, er diskriminerende (Clemet 2008). Men i Sverige argumenteres det med at tilbudet av fosterdiagnostikken uttrykker at «[...] ett barns så kallade brister utgör skäl för abort» (Andersson et al. 2008). Fosterdiagnostikk kan enten støtte seg på lover som tillater abort på bestemte indikasjoner, eller det kan støtte seg på lover som tillater «fri abort». Om det er loven eller testtilbudet som peker ut funksjonshemming som abortgrunn, kommer ut på ett. Kritikken mot fosterdiagnostikken behøver derfor ikke forstås gjennom et lands abortlov. Det handler om noe annet, og noe mer enn abort.

Snarere er det funksjonshemming som er problemet, eller mer presist formulert: forholdet mellom funksjonshemmede mennesker og fosterdiagnostikk. Et tidstypisk uttrykk er et dialogmøte på Island høsten 2007, arrangert av Nordisk Råd og den nordiske Bioetikk-komiteen (Norden 2007). Her fikk representanter for funksjonshemmedes organisasjoner i Norden fremlegge sin uro over den voksende utbredelsen av fosterdiagnostikk, i møte med genetikere, medisinere, politikere og etikere. Møtet kan leses som ett av mange symbolske uttrykk for at man i Norden til en viss grad har 
akseptert at fosterdiagnostikk har noe å gjøre med funksjonshemmede mennesker der ute i samfunnet. Det har ikke bare å gjøre med fosteret og dets eventuelle egenverdi eller menneskeverd, selv om flere fremtredende etikere, som Peter Singer og John Harris, har hevdet dette i en årrekke (Singer 1994: 220; Harris 1998: 215f). Selv om de etiske debattene omkring fosterdiagnostikk i Norden er av ulik styrke og omfang fra land til land, ser det altså ut til at et fellestrekk handler om «[...] att även barn med funktionshinder ska vara välkomna till denna värld,» som Karin Westlund og Barbro Gregorson i De handikappades riksförbund i Sverige har formulert det (Westlund \& Gregorson 2001).

Adrienne Asch har formulert denne kritikken til å dreie seg om beskjeden som sendes fra et tilbud om fosterdiagnostikk og abort. Et bestemt trekk identifiseres ved fosteret, og på basis av det uønskede trekket, velges abort:

As with discrimination more generally, with prenatal diagnosis, a single trait stands in for the whole, the trait obliterates the whole. With both discrimination and prenatal diagnosis, nobody finds out about the rest. The tests send the message that there's no need to find out about the rest. (Parens \& Asch 2000: 13)

Grunnlaget for å tilby rettede tester og å ta en avgjørelse om abort må nødvendigvis være vurderinger om hvordan et liv med en bestemt diagnose arter seg i praksis. Få blivende foreldre har kunnskap om dette på forhånd. Når testene peker mot et abortvalg, kan dette tolkes som en negativ vurdering av livene til konkrete mennesker der ute i samfunnet med den tilsvarende diagnosen. Men som Nancy Press har påpekt, må man ikke forstå beskjeden som å komme fra den enkelte gravides valg av abort. Den ekspressivistiske kritikken fokuserer ikke på «the choices made», men på «the choices made available» (Press 2000: 214).

Uroen som en del mennesker opplever i forhold til fosterdiagnostikk i de nordiske landene, handler ikke om en uro for dårligere levekår, skoleeller helsetilbud for funksjonshemmede mennesker. Snarere handler det om en uro på et dypere plan, nemlig uroen over en eventuell subtil melding som sendes til funksjonshemmede mennesker om at deres liv ikke anses av storsamfunnet som liv det er verdt å påbegynne. Som Lynn Gillam (1999) har påpekt, må det kunne oppleves krenkende at folk på utsiden skal saumfare ditt liv og vurdere hvor godt, eller dårlig, liv du har. Men samtidig, hevder Gillam, er ikke krenkelse eller fornærmethet det samme som diskriminering: «The fact that selective abortion is offensive to many people with disabilities does not in itself make selective abortion discriminatory to those who are offended by it.» (Gillam 1999: 163). Fosterdiagnostikken fornærmer, snarere enn den diskriminerer. 


\section{$\AA$ abortere en identitet}

Tim Stainton hevder fosterdiagnostikken ikke bare handler om et «signal» eller en «beskjed» til funksjonshemmede mennesker, men også noe mer. Problemet med Asch sin posisjon, sier Stainton, er at det settes en parantes rundt fosterets moralske verdi, og fokuset rettes utelukkende mot funksjonshemmede i samfunnet (Stainton 2003). Men dette gjør det lett for dem som ikke tilskriver fosteret moralsk status: Hva slags nedvurderende signal kan egentlig sendes fra en handling som i utgangspunktet er moralsk uproblematisk?

Staintons poeng er at forskjellen mellom den generelle og den selektive aborten også har implikasjoner for hvordan vi opplever fosterets moralske status. Ved generell abort handler det som regel om en uønsket graviditet, og fokuset ligger på egen livssituasjon. Ved selektiv abort styres fokuset mot barnets uønskede trekk og avvik. Dette er den såkalte «any-particular-distinction» som Asch har tematisert (Asch 2000: 236-239), altså forskjellen mellom å abortere et hvilket som helst foster og å abortere et foster «av denne typen». I det siste tilfellet kommer en identitetsbeskrivelse inn i bildet, en identitetsbeskrivelse som sier noe om hvordan og hvem dette fosteret er på godt og vondt, og hva slags liv det har i vente. Det er her Stainton radikaliserer den ekspressivistiske kritikken til også å omfatte fosteret: "Once identity-constituting characteristics are introduced, a specific subject is also introduced. We are no longer talking about any fetus, but a particular subject.» (Stainton 2003: 535).

Staintons argumentasjon er altså omtrent følgende: Fosterdiagnostikken skaper subjekter gjennom identitetsbeskrivelser. Beskrivelser av hvem dette fosteret vil kunne bli i fremtiden, er grunnlaget for abortbeslutningen. Stainton bekjenner seg altså til en konstruksjonistisk forståelse av moralsk status. Fostrene som aborteres i fosterdiagnostikken, blir subjekter for oss, nettopp fordi vi (tror vi) vet hvem de er. Fosterdiagnostikken er dermed i seg selv diskriminerende, hevder Stainton, i tillegg til at den sementerer uheldige identitetsbeskrivelser og en forståelse av det funksjonshemmede fosteret som radikalt annerledes. Ifølge Stainton forebygger man ikke sykdom og funksjonshemming i fosterdiagnostikkpraksisen, man aborterer identiteter og dermed subjekter.

Staintons konstruktivistiske posisjon har flere utfordringer knyttet til seg. Blant annet kan hans argumentasjon brukes også når man planlegger å unnfange et barn, men utsetter unnfangelsen som følge av at barnet kan få en bestemt alvorlig sykdom på akkurat dette tidspunktet, for eksempel dersom kvinnen har fått røde hunder (Parfit 1976). Også i slike tilfeller vil man jo forhindre at et bestemt menneske blir til fordi «man vet hvem det er». I så fall mister kritikken noe av sin kraft, for det virker lite rimelig å mene at et menneske som ikke engang er unnfanget, kan omtales som et subjekt. Poenget er imidlertid ikke her primært å drøfte holdbarheten ved denne 
posisjonen, men snarere bruke tankegangen til å komme nærmere det som står på spill i fosterdiagnostikkdebattene som følger dette sporet.

\section{Å skille diagnose fra person}

Både Asch og Stainton setter ord på hvorfor selektive aborter ofte oppleves som mer etisk problematisk enn generelle aborter. Men samtidig klarer ingen av dem å gi en bedre forståelse av hvorfor de etisk-politiske debattene kretser rundt Downs syndrom, mens det er relativt taust rundt diagnosegrupper som ryggmargsbrokk, muskeldystrofier, cystisk fibrose, Huntingtons sykdom og Klinefelter. At de offentlige debattene om fosterdiagnostikk primært handler om Downs syndrom, kan enkelt bekreftes gjennom et søk i digitale mediearkiver. Et søk i A-tekst for Norge gir 514 treff på kombinasjonen av «Downs» og «fosterdiagnostikk». Tilsvarende søk for «ryggmargsbrokk» og «fosterdiagnostikk» gir 24 treff, mens «cystisk fibrose» og «fosterdiagnostikk» kun gir 15 (A-tekst 2008).

Nærliggende forklaringer på fokuset på Downs syndrom i offentligheten kan være at Downs syndrom er en relativt hyppig diagnose (1:600), at det finnes diagnostikk som gjør det mulig å oppdage Downs syndrom i svangerskapet, at det i praksis viser seg at de fleste fostre som oppdages med Downs syndrom i de nordiske landene, aborteres og at alle gravide i prinsippet kan risikere å få et barn med Downs syndrom. Til sammen peker alle disse faktorene i samme retning. Det handler om Downs i fosterdiagnostikken.

Likevel er påstanden i denne artikkelen at en slik fremstilling ikke forteller hele sannheten. Alle gravide kan også i prinsippet få et barn med ryggmargsbrokk, tilstanden er hyppig (1:1000), og et høyt antall aborter inntreffer også på denne diagnosen, uten at det vekker den samme offentlige debatt som Downs syndrom. Dessuten er folk flest, og mange politikere med dem, nokså intetanende om hva som er de reelle tallene når det gjelder deteksjonsrater ved ultralyd og fosterdiagnostikk, forbruk av fosterdiagnostikk og reelle aborttall.

Trolig må man lete etter en mer fullstendig forklaring andre steder. Igjen kan løsningen ligge $\mathrm{i}$ å rette fokuset mot identitet, men denne gang ved å se på fraværet av sterke identitetsbeskrivelser ved bestemte diagnoser og tilstander. For mennesket som lever med en funksjonsnedsettelse, vil funksjonsnedsettelsen alltid være en del av livet. Asch er inne på et vesentlig poeng når hun som funksjonshemmet sier følgende:

During everyday life, people with disabilities do not think constantly about having a disability, but rather take necessary medications, use whatever methods they need to move, read, communicate, and get on with their lives of playing, studying, and working. (Asch 2000: 242) 
$\AA$ A ha en funksjonsnedsettelse eller kronisk sykdom behøver ikke være en sentral del av ens identitet, snarere kan det være en marginal del. Den er riktignok en del av den kroppen man har og er, men høyst andre ting i livet kan konstituere «hvem man er», ens selvforståelse og identitet.

Men følgen av dette poenget er ikke bare at gravide og samfunnet tar feil når de bare får øye på «avviket» og ikke hele personen, som Asch hevder. Det vel så viktige poenget er at for en rekke diagnoser vil det være lettere for offentligheten å skille person fra diagnose. Det vil være lettere å hevde at man i fosterdiagnostikken «aborterer» det antatte strevet, slitet og det upraktiske ved å ha en bestemt tilstand.

\section{Bortvalg av «sykdom og tragedie»}

Aller lettest er det antakelig å argumentere slik når man står overfor en potensiell alvorlig sykdom. Få mennesker ønsker å «feire» annerledesheten knyttet til å leve med en kronisk sykdom. Funksjonshemmedes interesseorganisasjoner har alltid vært opptatt av å understreke at man som funksjonshemmet ikke er syk. "Vi er indoktrinert til å se funksjonshemming som sykdom og tragedie,» mener Lars Ødegård, tidligere leder av det Norske Handicapforbundet (Rød 2006). Sitatet uttrykker to ting: For det første viser det at frigjøringskampen for funksjonshemmede har bestått i å få samfunnet til å slutte å betrakte funksjonshemming som patologi. De største barrierene mot deltakelse for mennesker med funksjonsnedsettelser, finnes i samfunnet og ikke i egen kropp. Det andre som sitatet kan uttrykke, er at om funksjonshemming ikke er sykdom og tragedie, så er sykdom fremdeles tragedie.

Mennesker som lever med (disposisjon for) alvorlig sykdom, opplever trolig i liten grad at fosterdiagnostikken er rettet «mot dem». Alvorlig kronisk sykdom passer ikke like godt inn i en sosial modell, og man har sånn sett ikke en «annerledeshet» ved seg som fosterdiagnostikken utfordrer. Det er den eventuelle smerten, belastningen, ubehaget og det upraktiske ved å være syk som fosterdiagnostikken «forebygger». Selv om man vet at for eksempel mennesker med den alvorlige lungesykdommen cystisk fibrose opplever å ha god livskvalitet (Wahl et al. 2003), kan fosterdiagnostikk ved cystisk fibrose fremdeles fremstå som et tilbud om bortvalg av strev og påkjenninger, og ikke et uttrykk for at disse livene ikke er leveverdige.

Ved sykdommer som først bryter ut sent i livet, ser man dette enda tydeligere. Huntingtons sykdom bryter som regel først ut mellom 30 og 55 år. Sykdommen bryter altså ut omtrent på det tidspunkt da den gjennomsnittlige cystisk fibrose-pasienten dør etter et liv med kronisk sykdom. Før denne tid har Huntington-pasienten ikke vært pasient i det hele tatt. Men det finnes ingen offentlige verdidebatter rundt bortvalg av fremtidige men- 
nesker med Huntingtons sykdom. Norge tillot i 2007 for første gang at preimplantasjondiagnostikk (PGD) ble brukt av et par ved en slik sent utbrytende sykdom (Dispensasjons- og klagenemnda 2007).

I 2006 ga det britiske Human Fertilization and Embryology Authority (HFEA) grønt lys for at kommende foreldre skulle kunne få bruke PGD til å velge bort fremtidige barn med disposisjon for arvelig brystkreft (Menon 2007). I 2008 ble PGD for første gang tatt i bruk i Israel for dette formålet, og hendelsen ble feiret i Jerusalem Post under overskriften «Hadassah breaks chain of BRCA mutation» (Siegel-Itzkovich 2008). Tilsynelatende er dette det sterkeste uttrykk for seleksjonssamfunnet: Seleksjonen omfatter nå også disposisjoner for sykdom som uansett først vil bryte ut sent i livet sykdom som faktisk kan forebygges. Men det er vanskelig å få øye på «beskjeden» som eventuelt skulle sendes fra slik seleksjon. Og det er vanskelig å se at kvinner med brystkreft eller med BRCA1- og -2 mutasjoner skulle oppleve at samfunnet nedvurderte deres liv. Tvert imot ville det være disse kvinnene som eventuelt etterspurte et slikt tilbud for å sikre seg at barna deres ikke måtte slite med de samme bekymringene som dem selv.

Dermed er det ikke sagt at PGD for sent utbrytende sykdommer og sykdomsdisposisjoner er etisk uproblematisk. Det er mer riktig å si at det reiser andre etiske utfordringer. Det eksisterer ikke et kontinuum mellom Downsproblematikken og brystkreftproblematikken. Bortvalg av arvelig brystkreft peker ikke mot identitets- og anerkjennelsesproblematikk. Og det er nettopp identitets- og anerkjennelsesproblematikken som etisk sett er den mest krevende.

\section{Downs syndrom og kampen for anerkjennelse}

De store verdidebattene rundt fosterdiagnostikken handler primært om diagnoser hvor man kan henvise til «annerledeshet», og hvor man påkaller samfunnets dårlige samvittighet for ikke å ville anerkjenne bestemte identiteter. Fravalgene i fosterdiagnostikken fremstår da som fravalg av «slike som meg». Bjørn Hatterud skrev i 2007 en kronikk i den norske avisen Aftenposten som nettopp argumenterte langs disse linjene. Hatterud, som selv hadde ryggmargsbrokk, brukte identitetsargumentet i sin kritikk av ultralydteknologi og fosterdiagnostikk: «Om ikke noe drastisk skjer, kommer vi med ryggmargsbrokk til å bli en utryddet minoritet. Du får ta meg i nærmere øyesyn, jeg er av en utdøende rase.» (Hatterud 2007). Hatteruds kronikk resulterte i en flom av leserinnlegg og kommentarer. Den hadde akkurat den effekten som Asch er opptatt av: å få oss til å se forbi diagnosen og funksjonsnedsettelsen og se det hele mennesket.

Tilsynelatende blir det vanskelig å skjønne hvorfor de offentlige debattene handler så mye om Downs syndrom, når ryggmargsbrokk ser ut til å 
være en like velegnet og aktuell diagnose å diskutere ut ifra. Men Hatteruds gjennomslag i den norske offentligheten med sin kronikk kan paradoksalt nok ses som en indikasjon på at han tok feil. Nettopp fordi Hatterud er som alle andre, til tross for sin funksjonsnedsettelse, så kan man bli opprørt av at «sånne som ham» aborteres bort. Hatterud ble kunsthistoriestudenten og musikeren med funksjonsnedsettelsen ryggmargsbrokk. Men med bekreftelsen av Hatterud som «normalvariant» blir trusselen fra fosterdiagnostikken samtidig mindre alvorlig. For ingen ønsker å velge bort kunststudenter eller musikere. Det trer klarere frem at abortvalg ved ryggmargsbrokk kan skje ved en (ev. feilaktig) henvisning om å unngå belastninger og påkjenninger, og ikke en nedvurdering av bestemte liv.

Forskjellen mellom en tilstand som ryggmargsbrokk og en tilstand som Downs syndrom kan trolig gripes gjennom å fokusere på kampen for anerkjennelse. Som Charles Taylor har påpekt, er identitet i moderne samfunn gjenstand for forhandlinger og kamp (Taylor 1995). Identitetsbeskrivelse er i flyt. Man er ikke bundet av klasse, arv og kaste i det moderne samfunn, men i betydelig grad frisatt. Samtidig hører identitet og anerkjennelse sammen. Hvem man er, kan ikke avgjøres $i$ isolasjon fra hvem andre mener man er. Man har ikke frihet til bare å bli den man har lyst å være. Anerkjennelsen må vinnes. I moderne samfunn pågår en kontinuerlig kamp for anerkjennelse. Og noen må kjempe hardere enn andre.

Diagnosen Downs syndrom er i den spesielle situasjon at den har gjennomgått radikale forandringer over kort tid. Fra en situasjon på 1930-tallet hvor «aandssvakhet» sto i fokus for steriliseringslovene i de skandinaviske landene, blir Downs syndrom i dag betegnet som mulighetenes syndrom. Fokuset ligger nå ikke på begrensninger, men på muligheter, tidlig stimulering, glede, trivsel og mestring (Lofterød 1997). Gjennomsnittlig levealder for individer med Downs syndrom har steget betydelig i løpet av de siste 40-50 årene, og et medisinsk fokus rettes mot intervensjoner som kan bedre livskvalitet og språkutvikling (Haugen et al. 2004). Den såkalte HVPUreformen i Norge på 1990-tallet innebar at mennesker med Downs syndrom ikke lenger ble institusjonalisert, men i større grad integrert i samfunnet. Siden 1970-tallet er normalisering og integrering sentrale stikkord for politikken som har blitt ført på funksjonshemmingsfeltet i Norge (Tøssebro \& Lundeby 2002). I 2001 ble Down Syndrome International stiftet i Portsmouth, England, og foreningen arrangerer hvert år Verdens Downs syndrom-dag. Feiringen er lagt til 21. mars - altså 21.03 - som symboliserer også en feiring av at man med Downs syndrom har tre kromosomer av kromosom 21. Tilsynelatende har identitetsbeskrivelser som gir rom for blomstring og gode liv, vunnet frem i en rekke moderne samfunn. Anerkjennelse har funnet sted.

Men på samme tid som mennesker med Downs syndrom lykkes på stadig nye fronter - for eksempel ved å ta førerkort, delta i teateroppsetninger 
eller lage TV-programmer - innføres det i de fleste nordiske land et fosterdiagnostikktilbud som altså kan føre til at mennesker med Downs syndrom nær sagt blir fraværende i fremtidens samfunn. Foreldre til barn med Downs syndrom blir usikre på om anerkjennelsen av gode identitetsbeskrivelser ved Downs virkelig er reell. Det utvikler seg en kamp om livskvalitetsbeskrivelser og mulighetspotensial ved diagnosen Downs syndrom. Få andre nettsider for foreninger og støttegrupper til barn med bestemte diagnoser har så mange kritiske artikler som omhandler fosterdiagnostikk som ved Downs syndrom. I Sør-Sverige satte foreldre til barn med Downs syndrom i gang underskriftskampanjer mot at «KUB-testen» (Kombinerat Ultraljud och Biokemi) skulle tilbys alle gravide (Sima 2007). Noe tilsvarende er nesten utenkelig for andre funksjonshemminger og sykdommer man tester for i fosterdiagnostikken.

\section{Diagnoser som kan settes i parentes}

Men kan man ikke også her, som med cystisk fibrose eller ryggmargsbrokk, hevde at det er antatte belastninger og bry kommende foreldre velger bort gjennom fosterdiagnostikk og abort? Er ikke folk flest i stand til å skille person fra diagnose også ved Downs syndrom, slik at fosterdiagnostikken slett ikke uttrykker mangel på anerkjennelse for bestemte identiteter?

Nok et blikk på forholdet mellom diagnosene ryggmargsbrokk og Downs syndrom kan belyse dette spørsmålet nærmere. Fra 1997 til 2000 hadde Norge en miljøvernminister med ryggmargsbrokk, Guro Fjellanger. Fjellangers funksjonsnedsettelse ble etter hvert kjent blant folk, og det ble laget dokumentarprogram om de barrierene Fjellanger møtte som minister. Blant annet måtte hun ta kjøkkeninngangen da hun skulle på festmiddag på det norske slott i anledning en internasjonal miljøkonferanse. For å kunne komme opp med rullestolen sin kjørte ministeren kjøkkenheisen, for deretter å ha den norske kongen til bords (Gjesvik 2006)

Det er ingen tvil om at det var barrierer for Fjellangers virke som minister, som ikke eksisterte for ministre uten funksjonsnedsettelser. Og det er heller ikke tvil om at disse barrierene i all hovedsak var samfunnsskapte, og at begrensningene ikke lå i Fjellangers kropp. Samtidig er Fjellangers historie en god illustrasjon av identitetsproblematikken. På den ene siden rettes fokuset i media mot Fjellanger som den første funksjonshemmede ministeren i Norge. Fokuset på funksjonshemmingen kunne tyde på at også Fjellanger ble ett med sin diagnose. Men på den andre siden er vinklingen i avisreportasjer og dokumentarfilm lagt på samfunnsskapte barrierer. Publikum blir hoderystende felles vitner til dårlig utbygd infrastruktur og manglende universell utforming. Diagnosen settes i parantes. Man innså at det er samfunnets skyld at den kom i forgrunnen. «Jeg er ikke ryggmargsbrokk. 
Det er ikke min primære identitet,» uttalte Fjellanger til en avis i 1997 (Ringheim 1997). Og leseren har ikke noe problem med å få øye på poenget. Etter hvert kom da også miljøpolitikken i forgrunnen. Funksjonsnedsettelsen ble glemt i offentligheten.

Fra manglende universell utforming av samfunnet er det rimelig å slutte at ideen om et absolutt inkluderende samfunn hvor alle er borgere fremfor brukere, er en idé som har slått rot sent i vår historie. Hvorvidt samfunnet $i$ dag kan kalles diskriminerende eller ei overfor funksjonshemmede dersom full tilgjengelighet ikke er sikret, eller er forsøkt utbygd i et ønsket tempo, er et diskusjonsspørsmål (NOU 2001:22). Men når det fokuseres på tilkortkommenhet på den praktiske innretningen av moderne samfunn, er det verdt å få øye på det idémessige landskapet: Det finnes ingen stemmer og ingen argumenter i debatten som taler mot universell utforming og likeverd. Ingen argumenterer i dag mot inkludering, likeverd og like rettigheter. Ministre med funksjonsnedsettelser er for lengst kommet for å bli. Det vil bare ta tid før vi praktisk får innrettet samfunnet slik at det stemmer overens med et idémessig landskap som tilsier nedbygging av alle funksjonshemmende barrierer. Fosterdiagnostikken vil neppe rokke ved denne utviklingen. Tvert imot vil den trolig øke fokuset på at ikke barrierer i samfunnet skal bidra til at kommende foreldre ønsker fosterdiagnostikk og eventuelt selektiv abort. Fosterdiagnostikken på dette feltet skriver seg altså inn i en diskurs om barrierer, bry og praktiske problemer. Den omhandler ikke anerkjennelsen av Guro Fjellanger som minister.

\section{Skuespillere med et ekstra kromosom}

Det er imidlertid her det blir mer sensitivt med funksjonsnedsettelsen Downs syndrom. For mennesker med Downs syndrom står nemlig det ekstra kromosomet i veien. Som tidligere beskrevet bør ikke dette forstås som en motsetning til at mennesker med Downs syndrom erobrer arenaer som knapt var tenkelige for noen tiår tilbake. I både Danmark, Norge og en rekke andre land i verden har mennesker med Downs syndrom inntatt hovedroller i både filmer, TV-serier og teaterstykker. Men til tross for slike prestasjoner forsvinner ikke diagnosen så lett fra offentlighetenes synsfelt. Den ser snarere ut til å være forbundet med personen på et komplisert vis. En person med Downs syndrom kan godt låne Fjellangers ord og si «Jeg er ikke Downs syndrom. Det er ikke min primære identitet». Men spørsmålet er om samfunnet virkelig anerkjenner en slik selvforståelse.

Et eksempel på dette er debatten som oppsto i Danmark etter at en kvinne med Downs syndrom skulle spille rollen som Ofelia i Hamlet på Danmarks Kongelige Teater i 2002. Tre av skuespillerne trakk seg i protest. En rasende Lars Von Trier foreslo å sparke de ansatte og stenge teateret på 
grunn av det han mente var genetisk diskriminering (Mikalsen 2002). Trier har selv utforsket tematikken omkring utviklingshemmede og autentisitet, og har antydet, blant annet gjennom filmen Idioten (1998), at man her har å gjøre med genuint alternative og autentiske identiteter (Solvang 2002). De ansatte på sin side hevdet at behandlingen av kvinnen med Downs syndrom var nedverdigende, at hun ble satt på utstilling, og at hun ikke skjønte rekkevidden av sine egne handlinger. Regissøren hevdet at diskusjonen om hvorvidt kvinnen med Downs syndrom skulle ha vært med eller ikke, burde tas av publikum som kom for å se stykket, og ikke de ansatte.

Hendelsen illustrerer at det finnes reelle og helt andre utfordringer for inkludering av mennesker med utviklingshemming kontra mennesker med fysiske funksjonsnedsettelser. Samtykkekompetansen er redusert, og sårbarheten er stor. Prosjektet kan feile, som med Hamlet i Danmark, eller det kan bli en suksess, som med Askepott i Norge (Rygg 2004). Begge steder forblir skuespilleren annerledes, og det ekstra kromosomet forsvinner ikke fra omtalen. Årsaken ligger i at skuespillere med utviklingshemming prinsipielt sett er avskåret fra å delta - eller mer presist formulert, veere deltakere på de samme premissene som skuespillere uten utviklingshemming. Funksjonsnedsettelsen forhindrer at skuespilleren med Downs syndrom kan avgjøre spørsmålene rundt hva som er utstilling av funksjonshemming, og hva som er en verdig rollefigur helt på egen hånd - like lite som utvinklingshemmede kan samtykke i å delta i medisinsk forskning helt på egen hånd. Det ekstra kromosomet fungerer som en beskyttelsesmekanisme for offentligheten for å forhindre uverdig behandling. Men dermed vil diagnose og person bli vanskelig å holde fra hverandre. Det blir en krevende balansegang mellom å behandle personer med utviklingshemming som deltakere (med fare for påføring av skade gjennom manglende beskyttelse) og som «deltakere» (med fare for påføring av skade gjennom overbeskyttelse og infantilisering). Identitets- og anerkjennelsesproblematikken er til forhandling.

\section{Aktivering og deaktivering av identitetslogikken}

Da den norske statsministeren valgte en minister med ryggmargsbrokk, ble ryggmargsbrokk en «normalvariant». I fosterdiagnostikken kan abort og embryoutvelgelse ved «normalvarianter» føre til en debatt om alvorlighetsgraden ved en tilstand - slik for eksempel alvorlighetsgraden av thalassemi ble diskutert etter den omstridte Mehmet-saken i Norge i 2004 (Bakke \& Førde 2004), eller alvorlighetsgraden ved ryggmargsbrokk ble diskutert etter Bjørn Hatteruds kronikk om ryggmargsbrokk i 2007 (Hatterud 2007). Vurderinger omkring ulempe, bry og belastninger kommer i forgrunnen. Praksisen behøver imidlertid ikke rokke ved selvforståelsen til grupper i 
samfunnet med tilsvarende funksjonsnedsettelser, fordi identitetsbeskrivelsene er godt forankret og står ikke på spill.

Når teateret velger en skuespiller med Downs syndrom, kommer annerledesheten inn i teateret. Man kan godt insistere på at abort ved Downs syndrom kun har å gjøre med antatt bry, belastninger og avhengighet, men for mange vil det alltid ligge en tvil her. Nettopp fordi mennesker med Downs syndrom markerer en annerledeshet, også når de inntar den normale scenen, så er identitetsbeskrivelsene skjørere og står mer på spill. Diagnose og person fremtrer - $\mathrm{i}$ alle fall for offentligheten - som tettere forbundet. Ingen i Norge i dag ville tenke at aborter som skjer på basis av diagnosen ryggmargsbrokk, handler om at man aborterte ministeren Fjellanger. Men ved Downs syndrom kan man ikke fri seg helt fra tanken på at man aborterer mennesket som ikke kan bli minister. Det er denne annerledesheten som settes i bevegelse av fosterdiagnostikken.

Om denne analysen er korrekt, gir den en mulighet til å forstå hvorfor etiske debatter rundt fosterdiagnostikken så ofte ender med å diskutere Downs syndrom. Denne funksjonsnedsettelsen er forenlig med et langt liv med god livskvalitet, og det har vist seg at man kan ta del i mange av de aktiviteter som andre mennesker tar del i. «Normaliseringen» av funksjonshemming har skapt uante muligheter for mennesker med Downs syndrom. Samtidig peker utviklingshemmingen mot en radikal form for annerledeshet. Dels tilsier den en annerledes deltakelse i en rekke praksiser. Dels tilsier den en begrenset form for deltakelse. Mennesker med Downs syndrom kan ikke bli foreldre eller ministre. Dette representerer ikke bare to "praksiser» blant mange, men kan ses som sentrale uttrykk for manglende intellektuell kompetanse. Deltakelse i det politiske liv og deltakelse i reproduksjon- og familieliv kan sies å representere både en klassisk og en moderne forståelse av det gode liv (Taylor 1989). Utviklingshemming er her et prinsipielt hinder for å kunne delta på samme vilkår som andre, og ingen universell utforming (endring av samfunnets institusjoner og infrastruktur for å tilpasses alle) kan trolig oppheve slike begrensninger. Sånn sett er Downs syndrom avskåret fra å bli en «normalvariant». Og nettopp derfor kan det synes som om diagnose og person er vanskeligere å skille ad.

Den medisinske forståelsen av «alvorlighetsskalaen» i fosterdiagnostikken fanger ikke opp identitetslogikken. Den argumenter ut fra en annen kode. Teresa Wagner og Regine Ahner illustrerer denne tankegangen når de uttaler redsel for en utglidning av fosterdiagnostikken mot «lette» tilstander som arvelig brystkreft. De frykter en utglidning mot «seleksjon» dersom PGD tas i bruk for lette tilstander (Wagner \& Ahner 1998). Yagel og Anteby (1998) deler skepsisen og trekker frem Downs syndrom som en paradigmatisk tilstand for prenatale screening programmer.

Men dermed blir de alle blinde for at frykten for «seleksjon» er mest relevant for den praksis som pågår akkurat nå. Om Huntingtons sykdom 
eller arvelig brystkreft utryddes gjennom PGD, kan man være kritisk til forbruket av embryoer, en manipulerende innstilling til livet, ressursbruken og påkjenningen fertile kvinner utsettes for, men neppe noen vil hevde at risikopersoner for Huntingtons sykdom eller arvelig brystkreft har blitt krenket eller nedvurdert gjennom denne praksisen. Det er «hovedpersonene» selv som her står for utvelgelsen, og de vil med troverdighet kunne hevde at de forebygger diagnoser og sykdommer, ikke identiteter.

Tanken på at Downs syndrom «utryddes» gjennom kontinuerlig og utstrakt bruk av fosterdiagnostikk og abort, reiser derimot spørsmålet om vi kan se mennesker med Downs syndrom inn i øynene og si at de er ønsket i samfunnet. Klarer vi å skille diagnose fra person i fosterdiagnostikkpraksisene? Klarer vi å holde fast på at abortpraksisen ikke har noe å gjøre med hvem disse menneskene er? Tesen i denne artikkelen er at dette er kjernen $\mathrm{i}$ seleksjonsdebatten og bakgrunnen for den uroen som en del mennesker føler.

\section{Alle onsker normale barn}

Alle foreldre ønsker friske barn, sies det ofte. Og det er helt legitimt å ønske seg friske barn. Men spørsmålet er om det ikke er riktigere å si at alle foreldre ønsker seg normale barn. Som David Heyd har påpekt, er reproduksjon forbundet med selvtransendens. De fleste mennesker ønsker i utgangspunktet genetisk egne barn. Samtidig ønsker man ikke kloner av seg selv. Reproduksjon handler selvsagt om mange ting, men videreføring av en selv i noe annet, er likevel et fremtredende trekk:

\footnotetext{
We want our offspring to be sufficiently like us so we can see them as our continuants, sufficiently similar to us so we can have a meaningful rapport with them. But we have no interest in exact mirror-images or in indistinguishable copies. The conception of parenthood in that respect is similar to Aristotle's idea of friendship, namely a relationship that extends our identity through an encounter with the partly different other. [...] We want to have children not only for the sake of the preservation of pure existence, but for the sake of continued humanity, namely existence under a particular description or identity. (Heyd 1991: 217)
}

En folkelig uttrykk for denne tanken er å si at alle ønsker barn i sitt bilde. Det betyr at litt annerledeshet er bra, mens mye oppleves som problematisk. Også funksjonshemmede foreldre kan ønske barn i sitt bilde. Nettopp ved funksjonsnedsettelser som er kjennetegnet av å være identitetskonstituerende, ser man i dag håndfaste bevis på hvor sterkt ønsket om et barn i ens eget bilde står. I en undersøkelse fra 2006 av amerikanske IVF-klinikker som tilbyr PGD, rapporterer 3 prosent at de har gjennomført embryoseleksjon (PGD) i den hensikt å gi et funksjonshemmet par et funksjonshemmet 
barn (Baruch et al. 2006). Døvhet er det paradigmatiske eksemplet her, selv om også andre tilstander som kortvoksthet er nevnt. Døve foreldre ønsker seg døve barn, og kortvokste foreldre ønsker kortvokste barn.

Normalitet er sånn sett kontekstuelt betinget til identiteter kommende foreldre forstår seg selv under. Som Isabel Karpin har påpekt, burde dette også være et tankekors for dem som hevder at vi automatisk styrer «[...] towards a race of blond, blue-eyed, able-bodied, intellectually magnificent and athletically superior beings» (Karpin 2007: 102). Dette er en typisk kritikk som man gjenkjenner fra nordisk debatt. Anne Grete Holmsgaard i Berlingske Tidende, uttrykker den slik: «I sin yderste konsekvens vil det føre til en udvikling, hvor man med teknologien og det fri individuelle valg $i$ hånden nærmer sig det, der betegnes som 'designerbørn'. Det pletfri barn til den pletfri familie.» (Holmsgaard 2008) Men vi styrer ikke mot det perfekte design. Vi styrer mot normalitet eller barnet i vårt bilde.

Når annerledesheten blir for stor, frykter vi, med Heyds ord, at vi ikke kan ha «a meaningful rapport» med våre barn. Foreldre som intetanende får et barn med Downs syndrom, får trolig ikke sterke sorgreaksjoner primært som følge av tanken på fremtidige belastninger. Det er vissheten om annerledesheten som skremmer dem. Eller sagt med Elisabeth Breens ord:

Å få et barn som var annerledes var som å få knust en drøm. Hvem drømmer ikke om det friske, normale barnet som skal vokse opp, fylle huset med spørsmål og svar og kjærlighet for så å fly sin vei når vingene er utvokst? [...] Å få et annerledes barn var å få en verden av tap i armene. En levende sorg med et særdeles mykt ansikt og lett skråstilte øyne. [...] I nesten to år sto jeg stille og stirret på den gamle drømmen. (Breen 2004: 43)

Elisabeth Breen, i likhet med de fleste andre foreldre til barn med Downs syndrom, kommer gjennom sorgen og opplever mulighetenes syndrom. De opplever at annerledesheten har en egenverdi som gir rom for andre erfaringstyper og andre opplevelser enn den gamle drømmen om det normale barnet. Og nettopp derfor blir fosterdiagnostikken et sårt punkt. Den synes å fiksere blikket på den problematiske annerledesheten de selv holdt blikket festet på da deres barn ble født. Den synes å fiksere en identitetsbeskrivelse som man selv og ens barn har lagt bak seg, når man nå opplever å leve gode og meningsfulle liv. Den synes å uttrykke at man ikke snakker sant. Ens forståelse av ens barn, og barnets selvforståelse anerkjennes ikke.

\section{Konklusjon}

Det står noe på spill i fosterdiagnostikken. Det er ikke uten grunn at «seleksjon», «eugenikk» og «sortering» har vært merkelapper brukt i de etiskpolitiske debattene om fosterdiagnostikken i de nordiske landene. Men den 
medisinske alvorlighetsskalaen klarer ikke å fange dette helt. Fraværet av en dimensjon - identitetsdimensjonen - gjør at de sterke verdidebattene rundt Downs syndrom blir til dels uforståelig fra et medisinsk ståsted. Fra dette ståstedet undrer man seg over at «alle snakker om Downs syndrom» når fosterdiagnostikk beviselig handler om veldig mye annet, ikke minst dødelige tilstander.

Først når man får øye på at noen tilstander og avvik skaper sterke identiteter, mens andre ikke gjør det, kan vi komme nærmere det som står på spill i fosterdiagnostikkdebattene. Vi behøver ikke innbille oss at det vi frykter, er en utvikling hvor vi gjør selektiv abort eller embryoutvelgelse på basis av feil øyenfarge. Det er ikke dette vi egentlig frykter. Vi frykter heller ikke at alvorlige arvelige sykdommer utryddes gjennom moderne teknologi, selv om det kan skje, og selv om det reiser en rekke andre etiske motforestillinger.

Det etisk betente i fosterdiagnostikken er forholdet til annerledeshet. Fosterdiagnostikken kan synes å reise tvil ved bestemte identitetsbeskrivelser. Den synes ikke å anerkjenne dem. Derfor fremstår fosterdiagnostikken som en trussel. Sterkest blir trusselen fra rettede masseundersøkelsesprogrammer. Downs syndrom blir i disse programmene et tema for hele den gravide populasjonen. I Danmark introduseres hvert år ca. 60000 gravide for valgmuligheter knyttet til testing for Downs syndrom. Det er ingen krav om indikasjoner som risiko, engstelse eller forhåndsbelastninger for prøvetaking. Fosterdiagnostikken fokuserer ikke primært på forebyggelse av engstelse i svangerskapet, fremtidige belastninger eller risikoreduksjon. Ettersom dette ikke er primærfokus, er det nærliggende å tenke seg at «annerledeshet» blir fokus i programmet.

Hvordan dette vil påvirke forståelsen av Downs syndrom som «mulighetenes syndrom», vet vi ennå ikke. Det er komplisert å skulle klare å påvise eventuelle sammenhenger mellom tilbudet av fosterdiagnostikk og svekket anerkjennelse av annerledesidentiteter for mennesker med Downs syndrom. Men vi kan ikke utelukke at det finnes en sammenheng.

Selvsagt er hensynet til kvinnens autonomi og selvbestemmelsesrett over egen kropp svært viktig. Denne artikkelen har ikke drøftet slike hensyn eller forsøkt å veie dem opp mot hverandre. Det er heller ikke trukket inn kompliserende faktorer som at diagnoser kan romme store spenn i alvorlighetsgrad. Formålet her har kun vært å påvise at det er reelle grunner for å drøfte fosterdiagnostikk opp mot ideen om et inkluderende samfunn og identitetsbeskrivelsene et slikt samfunn gir rom for.

En ytterliggående løsning på noen av disse utfordringene er lansert av Torbjörn Tännsjö. Skal vi unngå at samfunnet gjør vurderinger av funksjonshemmede menneskers liv, er eneste løsning å innføre en uregulert fosterdiagnostikk - altså en praksis hvor man kan teste for hva man vil, og abortere på hvilket som helst grunnlag (Tännsjö 1991: 108). Da vil det ikke 
finnes «dødslister» som angir hvilke tilstander som gir grunnlag for abort. Om Tännsjö har aldri så rett i sin advarsel mot lister som i klartekst definerer hvilke liv som står til vurdering i samfunnet, så bommer han på to viktige punkter. For det første har uttrykket «dødslister» bare en rammende kraft så lenge vi har å gjøre med menneskelige identiteter som kjemper for anerkjennelse. Kvinner med brystkreftdisposisjon vil aldri oppleve at de er uberettiget i samfunnet. For det andre blander Tännsjö sammen «the choices made» og «the choices made available». Det er samfunnets tilbud av fosterdiagnostikk, og ikke abortvalgene eller avgjørelsene i abortnemndene, som stimulerer kritikken om at samfunnet ikke anerkjenner bestemte identiteter. Resultatet er at heller ikke Tännsjö får øye på at den vanskelige etiske diskusjonen i bunn og grunn handler om Downs syndrom.

Når fosterdiagnostikk tilbys som screening av alle gravide med et uttalt formål om å avdekke fostre med Downs syndrom, så gir dette en reell mulighet for at fremtidens samfunn er et samfunn uten mennesker med Downs. I motsetning til samfunnet uten brystkreft, er det vanskeligere å bejuble dette. Det er vanskeligere å utelukke at bortvalget har skjedd som følge av hvem disse menneskene antas å være. Og i så fall øker utryggheten om samfunnet vi lever i kan kalles «inkluderende». Noe av dette er kjernen $i$ at «vi» paradoksalt nok frykter et samfunn uten Downs syndrom.

\section{Litteratur}

Andersson, A., Bengtsson, M., Brunegård, G. \& Svensson, S. Å. (2008) Våga tala klarspråk om fosterdiagnostik. Barometern, 24. januar 2008.

Asch, A. (2000) Why I haven't changed my mind on prenatal diagnosis. I Prenatal Testing and Disability Rights, red. E. Parens \& A. Asch, s. 234-261. Washington: Georgetown University Press.

A-tekst (2008) Det digitale retriever mediearkivet. Lastet ned 12. februar 2008 fra http://www.retriever-info.com/atekst.php

Bakke, H. K. \& Førde, R. (2004) Medisinske verdivalg. Dagbladet, 18. mars 2004.

Baruch, S., Kaufman, D. \& Hudson, K. (2006) Genetic testing of embryos: Practices and perspectives of U.S. IVF-clinics. Fertility and sterility, 20. september 2006 (article in press DOI: 10.1016/j.fertnstert.2006.09.003).

Bojesen, A., Juul, S. \& Gravholt, C. H. (2003) Prenatal and postnatal prevalence of Klinefelter syndrome: A national registry study. The Journal of Clinical Endocrinology \& Metabolism, 88 (2), s. 622-626.

Breen, E. (2004) Et samfunn for alle. I Med Downs gjennom livet, red. K. Bogen, M. Weitemeyer \& M. Aalandslid, s. 41-57. Kolofon.

Broberg, G. \& Roll-Hansen, N. (1996) Eugenics and the welfare state - sterilization policy in Denmark, Sweden, Norway and Finland. Michigan: Michigan University Press.

Clemet, K. (2008) Veien til helvete. Aftenposten, 6. februar 2008. 
Dispensasjons- og klagenemnda for behandling av saker i utlandet (2007). Saksnr.: 07/29. Tilgjengelig på www.klagenemnda.no

Getz, L. \& Kirkengen, A. L. (2003) Ultrasound screening of pregnancy: Advancing technology, soft markers of fetal anomaly and unacknowledged ethical dilemmas. Social Science and Medicine, 56 (10), s. 2045-2057.

Gillam, L. (1999) Prenatal diagnosis and discrimination against the disabled. Journal of medical ethics, 25, s. 163-171.

Gjesvik, A. (2006) Hemmetfronten. Dagens noringsliv, 10. juni 2006.

Harris, J. (1998) Clones, genes and immortality. Oxford: Oxford University Press.

Hatterud, B. (2007) Jeg er av en utdøende rase. Aftenposten, 8. februar 2007.

Haugen, O. H., Høvding, G. \& Riise, R. (2004) Øyeforandringer ved Downs syndrom. Tidsskriftet for den norske loegeforening, 124, s.186-188.

Helse- og omsorgsdepartementet (2007) Forslag om endringer i bioteknologiloven lagt fram for Stortinget. Pressemelding, nr. 5, 26. januar 2007.

Heyd, D. (1991) Genethics - moral issues in the creation of people. Berkeley: University of California Press.

Holmsgaard, A. G. (2003) Det pletfri barn. Berlingske Tidende, 8. mai 2003.

Karpin, I. (2007) Choosing disability: Preimplantation genetic diagnosis and negative enhancement. Journal of law and medicine, 15 (1), s. 89-102.

Lofterød, B. (1997) Mulighetenes syndrom. I Hver for seg små - sammen store, red. E. Ruud \& B. Nilsson, s. 89-97. Frambu senter for sjeldne funksjonshemninger.

Magerøy, L. H. (2005) SV-politikk ligner Nazi-Tyskland. Vårt Land, 1. juni 2005.

Menon, U., Harper, J., Sharma, A., Fraser, L., Burnell, M., Masry, E., Rodeck, C. \& Jacobs, I. (2007) Views of BRCA gene mutation carriers on preimplantation genetic diagnosis as a reproductive option for hereditary breast and ovarian cancer. Human Reproduction, 22 (6), s. 1573-1577.

Mikalsen, E. H. (2002) Lars von Trier raser mot skuespillerne. Dagbladet, 7. august 2002.

Munthe, C. (1996) The moral roots of prenatal diagnosis - ethical aspects of the early introduction and presentation of prenatal diagnosis in Sweden. Göteborg: Centre for research ethics.

Norden (2007) [konferanse] Dialogue on Dignity, Disability, Discrimination and Diagnostics. Den nordiske bioetikk-komiteen, Reykjavik, 19.-20. oktober 2007.

NOU (2001:22) Fra bruker til borger - en strategi for nedbygging av funksjonshemmende barrierer. NOU-rapport. Oslo: Statens forvaltningstjeneste.

Parens, E. \& Asch, A. (2000) The disability critique of prenatal testing. I Prenatal testing and disability rights, red. E. Parens \& A. Asch, s. 3-44. Washington DC: Georgetown University Press.

Parfit, D. (1976) Rights, interests and possible people. I Moral problems in medicine, red. S. Gorovitz, s. 369-375. New York: Prentice-Hall.

Press, N. (2000) Assessing the expressive character of prenatal testing: The choices made or the choices made available? I Prenatal testing and disability rights, red. E. Parens \& A. Asch, s. 214-234. Washington DC: Georgetown University Press.

Ringheim, T. (1997) Med brokk og politikk i ryggmargen. Dagbladet, 21. september 1997.

Rygg, E. (2004) Annerledes og rørende Askepott. Aftenposten, 19. april 2004.

Rød, S. (2006) Pioner i brytningstid. Handikapnytt, 4. 
Schei, B. (1992) The routine use of ultrasound in antenatal care: Is there a hidden agenda? Issues in reproductive and genetic engineering - Journal of international feminist analysis, 5 (1), s. 13-20.

Siegel-Itzkovich, J. (2008) Hadassah breaks chain of BRCA mutation. The Jerusalem Post, 25. februar 2008.

Sima, J. (2007) Protester mot fosterdiagnostik. Kvällsposten, 27. august 2007.

Singer, P. (1994) Rethinking life and death - the collapse of our traditional ethics. New York: Oxford University Press.

Solvang, P. (2002) Annerledes - uten variasjon, ingen sivilisasjon. Oslo: Aschehoug. Socialdepartementet (2004) Genetisk integritet. Kommittén om gentisk integritet. Pressmeddelande, 5. mars 2004. Lastet ned 1. februar 2008 fra http://www.regeringen.se/sb/d/119/a/16 573

Stainton, T. (2003) Identity, difference and the ethical politics of prenatal testing. Journal of Intellectual Disability Research, 47 (7), s. 533-539.

Sundhedsstyrelsen (2003) Fosterdiagnostik og risikovurdering - rapport fra en arbeijdsgruppe. København: Sundhedsstyrelsen.

Taylor, C. (1995) The politics of recognition. I Philosophical Arguments, red. C. Taylor, s. 225-257. Cambridge: Harvard University Press.

Taylor, C. (1989) Sources of the self - the making of the modern identity. Cambridge: Cambridge University Press.

Tännsjö, T. (1991) Välja barn - om fosterdiagnostik och selektiv abort. Stockholm: Sesam.

Tøssebro, J. \& Lundeby, H. (2002) ^ vokse opp med funksjonshemming. Oslo: Gyldendal Akademisk Forlag.

Wagner, T. \& Ahner, R. (1998) Prenatal testing for late-onset diseases such as mutations in the breast cancer gene 1 (BRCA1) - just a choice or a step in the wrong direction? Human Reproduction, 13 (5), s. 1125.

Wahl, A. K., Rustøen, T., Gjengedal, E., Homme, J. \& Hanestad, B. R. (2003) Cystisk fibrose i et pasientperspektiv. Tidsskriftet for den norske loegeforening, 123, s. 2580-2582.

Westengaard, L. (2006) Nytt tilbud til alle gravide. Sundstrømmen, 1 (5).

Westlund, K. \& Gregorson, B. (2001) Fosterdiagnostik kan bli framtidens rashygien. Handikappförbundet. Lastet ned 1. februar 2008 fra http:// www.ikapp.nu/view.asp?SubjectID $=10$

Yagel, S. \& Anteby, E. (1998) A rational approach to prenatal screening and intervention. Human Reproduction, 13 (5), s. 1126. 